Accounting and Management Information Systems

Vol. 19, No. 3, pp. 543-565, 2020

DOI: http://dx.doi.org/10.24818/jamis.2020.03005

\title{
The influence of emotional intelligence on auditor performance
}

\author{
Richard G. Brody ${ }^{\mathrm{a}}$, Gaurav Gupta ${ }^{\mathrm{b}, 1}$ and Stephen B. Salter ${ }^{\mathrm{c}}$ \\ ${ }^{a}$ University of New Mexico \\ ${ }^{\mathrm{b}}$ University of North Carolina Wilmington \\ ${ }^{\mathrm{c}}$ Middle Tennessee State University
}

\begin{abstract}
Research Question: How does Emotional Intelligence influence auditor performance?

Motivation: Emotional Intelligence has been researched as one of the critical factors that are linked to superior work performance. However, this research is still in its infancy with respect to auditors despite the fact that the auditing profession would benefit greatly from improving the work performance of its professionals. In this paper, we address this issue and lay the foundation for a future paper that would analyze the impact of increasing the emotional intelligence of auditors on their task performance. We hypothesized that emotional intelligence is positively related to auditor performance.

Data: Undergraduate accounting and MBA students were selected to participate in this study. Sixty-nine participants completed the Emotional Intelligence inventory provided by Genos International, Australia and performed a simple audit activity designed by the authors for this study. Multiple regressions were utilized to analyze the data.

Findings: The hypothesis was not supported, and the paper addresses this result as well as provides guidance to future researchers in this significant area. Contribution: Because of the challenges associated with this type of experiment as well as the lack of existing research in the area, this paper uses student subjects to provide initial feedback on the effectiveness of the instrument. The results will help guide future research and, as an added benefit, preserves the subject pool of practicing auditors.
\end{abstract}

${ }^{1}$ Corresponding author: Gaurav Gupta, Assistant Professor, Department of Accountancy and Business Law, Cameron School of Business, University of North Carolina Wilmington, 601 S. College Rd, Wilmington, NC 28403, Phone: (910) 962-2798, email address: guptag@uncw.edu 
Keywords: Emotional Intelligence, Auditor Performance, Genos International Inventory

\section{JEL Codes: M41}

\section{Introduction}

Today, the academic literature is full of Emotional Intelligence (EI) models. EI refers to a person's ability to understand and use emotions to make decisions. Mayer and Salovey define EI as "the ability to perceive accurately, appraise, and express emotion; the ability to access and/or generate feelings when they facilitate thought; the ability to understand emotion and emotional knowledge; and the ability to regulate emotions to promote emotional and intellectual growth" (Mayer \& Salovey, 1997: 10). Mayer and Salovey's (1997) EI model contain the following four branches: Perceiving emotions, Using emotions, Understanding emotions, and Managing emotions.

The concept of EI, although developed in early 1960s, had not been researched until the last two decades. Goleman (1998) posits that EI is twice as important as Intelligence Quotient (IQ) for task performance, and that organizations can improve the EI of their members for improving employee productivity and performance. Previous studies in psychology, health, and performance measurement (Slaski \& Cartwright, 2002; Lam \& Kirby, 2002) have provided strong evidence of the positive relationship between EI and job performance. Although the role of EI in improving task performance has been well-researched in several disciplines, its importance in improving the quality of the audit function has not yet been adequately established. Therefore, research is needed on how EI affects the performance of auditors and whether it can/does improve the quality of audit engagements. This research uses student subjects as surrogates for auditors and evaluates the impact of increased EI awareness on auditor performance.

There are several reasons for undertaking this study. First, there is a dearth of accounting literature examining the impact of increasing auditor's EI on their task performance. This is important to consider especially when the role of EI in other disciplines is well-documented. Using the Workgroup Emotional Intelligence Profile (WEIP) scale (Jordan \& Lawrence, 2009), Yang et al. (2018) find that the moderating effect of EI can help in improving audit quality by minimizing auditors' tendency to engage in dysfunctional behavior. Second, this research aspires to reduce audit risk for accounting by promoting better decision-making by auditors. This, in turn, would lower the likelihood of litigation and lead to more efficient and effective audits. Audit firms could increase their profits or use this 
efficiency to lower audit fees. Ashbaugh-Skaife et al. (2009) stated that riskiness (as measured by firm's stock's beta) and financing costs (i.e., cost of equity, etc.) are higher for firms that reported problems in internal controls. We believe that a positive relationship between EI and their performance would increase audit clients' firm value by increasing the likelihood of detecting fraud or mitigating the likelihood of fraud through the strengthening of internal controls. Finally, improvement in auditor performance is likely to provide additional credibility to a client's financial statements, which in turn, would enhance public confidence in the capital markets of a country.

This paper continues with a literature review, hypothesis development, discussion of variables, data and research methodology, and results. We end with the limitations of the present study and provide directions for future research.

\section{Literature review}

\subsection{Previous research on audit quality and auditor performance}

Auditing research is full of studies with varied themes. The popular research themes that appeal to most investors, regulators, audit firms and clients deal with issues of audit quality and auditor performance. In this literature review, we provide a summary of existing research for these two areas of audit research. Many studies have examined factors that are related to audit quality (e.g., Ernstberger et al., 2020; Hollingsworth et al., 2020; Salehi et al., 2019; Van Brenk et al., 2019; Carcello et al. 2000; Trompeter, 1994).

In a recent study, Ernstberger et al. (2020) examine the role of audit firms' compensation policies on audit quality. Using data from the annual transparency reports of German audit firms, the authors note that the compensation policies vary across the firms and two characteristics of audit compensation (profit sharing in a small profit pool and high variable compensation) are negatively associated with audit quality. Utilizing agency theory and reinforcement sensitivity theory, Ven Brenk et al. (2019) examine the role of an audit partner profit-sharing plan, the level of client importance, and the impact of auditor reinforcement sensitivity on audit quality. The authors conclude that "the highest audit quality is achieved where profit sharing is based on firm performance, client importance is low, and reinforcement sensitivity is high" (p. 30).

In another study, Hollingsworth et al. (2020) examine the impact of change in an audit firm's issuing office on the audit quality and audit fees. The authors found "that companies that have a change in their audit firm's issuing office exhibit a decrease in audit quality and an increase in audit fees" (p. 71). Hollingsworth et al. (2020) also further bifurcate changes in audit firm's issuing office into two 
categories: (1) client driven changes and (2) audit firm driven changes. The authors found that audit firm driven changes in issuing office result in reduction in audit quality but no changes in audit quality occur when the change in the issuing office is driven by the client.

Another theme in auditing research is the examination of factors that can influence auditor performance. Different studies (e.g., Sunyoto, 2020; Ghadhab, et al., 2019; Downey, 2018; Murthy \& Wheeler, 2018; Affifah, 2015; Peytcheva, 2014) have identified factors that influence auditor performance. Downey (2018), for example, evaluates the role of work redesign caused by offshoring in audit practice on auditor performance. The author reports "that performance declines when participants complete work from a point in progress that is perceived to be of less significance" (p. 197). In another study, Adnyana and Mimba (2019) examine the impact of task complexity and time pressure on the performance of auditors at the Public Accountant Office in Bali, Indonesia. The authors also examine the moderating effects of compensation and organizational citizenship behavior on the relationship between the dependent and independent variables. The authors reported that both task complexity and time pressure negatively influenced auditor performance. Organizational citizenship behavior significantly moderated the relationship between time pressure and auditor performance. The other moderator, compensation, was not significant.

In the current study, we examine the influence of emotional intelligence on auditor performance. Mayer and Salovey (1997: 10) define EI as "the ability to perceive and express emotion, assimilate emotion in thought, understand and reason with emotion, and regulate emotion in the self and others." Research on EI has gained momentum in the previous decade to measure its influence on an individual's task performance in different contexts. The influence of emotions behaviors and decision-making is widely recognized in other research disciplines such as accounting (Yang et al., 2018), offshoring (Gupta et al., 2019), organization behavior (Ashforth \& Humphrey, 1995), and psychology (Lewis \& HavilandJones, 2000). Prior research substantiates that emotions play a vital rule in proving information cues about the environment, thereby assisting in thought process and making decisions in different contexts. This is contrary to the previously held myths that individuals' emotions should not interfere with their workplace behaviors.

"Perceiving emotions consists of recognizing and interpreting the meaning of various emotional states, whereas regulating emotions encompasses the control of emotions in oneself and in others" (Lam \& Kirby, 2002: 139). Mayer et al. (1999) describe EI as a cognitive ability that reflects a person's ability to understand and reason regarding emotions. Several studies have found a positive relationship between EI and organizational performance as well as ability to make decisions in a team environment (e.g., Kearney et al., 2017; Brackett et al., 2006; Goleman et 
al., 2002; Rego et al., 2007). Slaski and Cartwright (2002) found that EI had a positive impact on the performance of retail managers in a large retail organization. The authors note that EI moderates the process of work stress and, as such, optimizes an individual's performance. In another study, Cavallo and Brienza (2001) conducted a study on 350 managers from Johnson \& Johnson and concluded that high performance leaders at Johnson \& Johnson had higher levels of EI than low performance leaders.

Lam and Kirby (2002) researched with 302 undergraduate students to identify the differences in the cognitive-based task performance of undergraduate students who were grouped into high and low EI levels. They asked the students to complete 8 difficult logical reasoning problems and told them that their performance will be measured on the basis of both the time taken to complete the task and number of correct responses. Lam and Kirby (2002) found that there was a significant positive relationship between the EI of students and their performance on the cognitivebased tasks.

EI has relevance for auditing for several reasons. EI can help in improved decisionmaking by augmenting skills auditors need to possess for performing their jobs effectively. Over the last decade, the auditing profession has changed drastically. Auditors are required to review and analyze a company's processes, operations, systems and financial statements and make judgements about their efficacy or fairness. The work of the auditors is scrutinized by many different parties (e.g., peer reviewers, regulators) and one lawsuit can force an accounting firm into bankruptcy. Thus, it is paramount that auditors make good decisions and anything that can lead to better decision making is something the profession and other parties would be interested in. Prior research (Ismail \& Rasheed, 2019; Ismail, 2015) has also started to examine the link between emotional intelligence and ethical decisions made by individuals. Collecting data from over 250 auditors in Malaysia, Ismail (2015) examines the influence of emotional intelligence, corporate ethical values and different ethical climates on the ethical judgment of auditors. The author noted that auditors' emotional intelligence levels and corporate ethical values positively influenced ethical judgments by auditors. The author studied the five types of ethical climates - professionalism, caring, rules, instrumentalism, and independence (Victor \& Cullen, 1988). Interestingly, the author found that instrumental and independence climate negatively influenced the ethical decisions of auditors.

Auditors also need to possess excellent communication and interviewing skills to gauge when the client is being honest and when not. Finally, auditors need to have professional skepticism to look for the possibility of misstatement or fraud as well to critically examine the audit evidence and related documentation. EI can provide support as "auditors build and maintain positive, productive relationships throughout the organization" (Jacka, 2018: 36). Yang et al. (2018) examine the 
moderating role of EI on the relationship between time budget pressure and client pressure, and auditor judgment. The authors conclude (p. 83):

The results suggest that the moderating influence of EI can effectively reduce auditors' tendency to engage in dysfunctional behavior and improve audit quality. Further, moderation analysis suggests that EI is a significant mechanism that moderates the effects of different types of pressure on auditors' judgments.

Further, as each audit is a project, which is temporary, unique, and may involve change given its unique circumstances. Clarke and Howell (2010) conducted a study with project managers and found that there exists a significant relationship between EI and project manager competence, and successful project completion. Further, Daff et al. (2012) also note the importance of emotional intelligence skills for enhancing the employability of the accounting graduates. Therefore, we believe that EI skills hold utmost importance for auditors to enhance their work performance.

Auditors frequently work in teams to complete different kinds of audits of their clients. These individual audits have two distinct characteristics. One, most, if not all, audits require teamwork, wherein team composition may change with each audit itself. EI has been shown to improve team performance. Ilarda and Findlay (2006) found that EI was positively associated with team orientation. Also, Ayoko et al. (2008) state that there was a positive link between EI and team performance on account of less task and relationship conflict. Rice (1999) conducted a study with 164 employees grouped in 26 teams of a large insurance company and concluded that managers awarded higher performance ratings to teams with higher average emotional intelligence scores. Higher employee EI is likely to benefit both employer in terms of enhanced firm revenues and profitability, and employee in terms of increased career growth, and financial and non-financial incentives. One prerequisite to efficient team performance is the ability of individual members to work with other members and contribute to the group decision making. Overall, EI can lead to better decision-making, which in turn, leads to better outcomes for both employees and employers. For an auditing firm, that may translate to a lower likelihood of a failed audit and reduced liabilities.

\subsection{Seven factor emotional intelligence model of Genos International}

In the current research, we utilize the seven-factor Emotional Intelligence model developed by Genos International. As per the Genos Emotional Intelligence Inventory: Technical Manual, the model is suitable for demonstration to adults over 18 years old and developed specifically for understanding EI in workplace behaviors. Per the technical manual (p. 11-13), the seven-factor model contains the following branches of EI: 
Emotional Self-Awareness (ESA): "Emotional Self-Awareness measures the relative frequency with which an individual consciously identifies their emotions at work."

Emotional Expression (EE): "Emotional Expression measures the relative frequency with which an individual expresses their emotions in an appropriate way at work."

Emotional Awareness of Others (EAO): "Emotional Awareness of Others measures the relative frequency with which an individual identifies the emotions expressed by others in the workplace."

Emotional Reasoning (ER): "Emotional Reasoning measures the relative frequency with which an individual incorporates emotionally relevant information in the process of decision making or problem solving at work."

Emotional Self-Management (ESM): "Emotional Self-Management measures the relative frequency with which an individual manages their own emotions at work, successfully."

Emotional Management of Others (EMO): "Emotional Management of Others measures the relative frequency with which an individual manages the emotions of others at work, successfully."

Emotional Self-Control (ESC): "Emotional Self-Control measures the relative frequency with which an individual controls their strong emotions appropriately in the workplace."

Additionally, total EI score is also provided, which is "based on an equally weighted composite of the seven Genos EI dimensions" (Gignac, 2010, p. 15). In the present research, we use participants' total EI scores to analyze its impact on the task performance by participants in our study. We now proceed to develop our hypothesis.

\section{Hypothesis development}

Prior studies (Druskat \& Wolff, 2001; Goleman et al., 2002; Rego et al., 2007) in a variety of disciplines have highlighted the importance of EI in improving individual work performance. From the perspective of the accounting profession, Akers and Porter (2003: 65) note that "EI skills are critical for the success of the accounting profession." Recently, in a report entitled "Emotional quotient in a digital age" (2018: 7), Helen Brand, chief executive of ACCA stated: 
Many people have an intuitive sense of EQ, often expressed as something to do with emotions and interacting effectively with people. But it is important to go beyond this and critically reflect on the value embedded in emotions in today's digital age.

The present research examines the impact of EI on auditor performance. Using students as a surrogate for auditors, we examine if EI has an impact on performance on an audit activity. Building on the prior literature, we develop the following hypothesis:

H1. Emotional intelligence is positively associated with auditor task performance.

\section{Variables}

\subsection{Independent variable: total emotional intelligence}

EI is measured by the 31-item inventory developed by Genos International. Each item of the survey is scored on the five-point Likert scale from "Almost Never (1)" to "Almost Always (5)." A copy of the survey is attached in Appendix A.

\subsection{Dependent variable: auditor performance}

Auditor Performance is measured by the number of correct responses on the audit activity. Auditor performance is a continuous variable with a possible score range of 0-9. A score of zero means that a student got all questions wrong and a score of nine means that a student got all questions right on the audit task. A copy of the survey is attached in Appendix B.

\subsection{Control variables}

In order to analyze the relationship between EI and auditor performance, we also collected data on various control variables such as the age of participants, number of accounting courses taken, and years of full-time experience in accounting/accounting related fields. However, as most students possessed no work experience, this variable was not included in the regression model.

\section{Data collection and research methodology}

The data for this study came from undergraduate and MBA students enrolled in a large public U.S. university. Although emotional intelligence has been gaining popularity in the organizational and management discipline, its role and benefits for auditors have been not fully explored yet. Therefore, instead of using practicing 
auditors, we decided to develop an experiment and conduct the study with students. Audit professionals willing to participate in this or any research are in great demand and are a limited resource. Moreover, our goal was to run a complete study with two levels of students (undergraduate and graduate) to obtain initial evidence regarding our case materials with the idea that refinements would be necessary. Moreover, multiple studies (e.g., Chand et al., 2012; Banker et al. 2011; Tayler, 2010; Banker et al., 2004; Lipe \& Salterio, 2000) published in different accounting journals have utilized student subjects. Lipe and Salterio (2000) collected data from 58 first year MBA students to conduct their experiment. They published their research on the issue of balanced scorecard in the Accounting Review, a top scholarly journal in accounting. Banker et al. (2011) also utilized data from MBA students to analyze the judgmental effects of strategy maps in balanced scorecardbased performance evaluations. The study was published in another high-ranked accounting journal, International Journal of Accounting Information Systems. Chand et al. (2012), on the other hand, utilized data from final year undergraduate accounting students, to analyze the effect of national culture and education on the interpretation and application of selected IFRS. Further, a large number of studies (e.g., Liyanarachchi, 2007; Libby et al., 2002; Ashton \& Kramer, 1980) have justified utilizing accounting students as surrogates for accounting professionals. For example, Liyanarachchi (2007) notes "that students might be good surrogates for accountants in studies that involve human information processing and decisionmaking tasks" (Chand et al., 2012: 164). Therefore, we believe the existing literature supports our use of student subjects and we do recognize the potential limitations later in the paper.

Students first completed the Emotional Intelligence inventory, which was obtained through Genos International in Australia. In addition to answering 31 questions relating to EI, the students also answered demographics questions relating to their age, nationality, and experience levels. After completing the survey instrument, all participants were asked to perform a small audit activity. In the audit activity, we provided a hypothetical client's financial statements (balance sheet and income statement) and other important information. The financial statements were based on an actual publicly held company and the additional information was added as part of the experimental materials. The participants were told that the "other important information" was assumed to found by them, which were followed by a series of questions. All participants were recruited through contacts with different instructors who were teaching accounting courses at the time of the survey. All participants completed the entire activity within 50 minutes.

The scores on EI were provided by Genos International. Per information provided in the technical manual of the Genos Emotional Intelligence Inventory, "the total EI score is based on an equally weighted composite of the seven Genos EI dimensions" (p. 13). Multiple linear regressions were conducted to analyze the impact of participants' EI on auditor performance. The following research model was analyzed: 
Auditor Performance $(Y)=\alpha+\beta 1$ Total EI $+\beta 2$ Age $+\beta 3 \mathrm{ACCT}+\mu$

wherein,

Total EI = Participant's Total Emotional Intelligence

Age $=$ Participant's age (in years)

$A C C T=$ Number of accounting courses taken by participants

We also conducted t-tests to examine if significant differences exist between the EI levels of MBA and undergraduate students.

\section{Results}

Table 1. Descriptive statistics

\begin{tabular}{|c|c|c|c|c|c|c|c|c|}
\hline & \multicolumn{4}{|c|}{$\begin{array}{l}\text { Undergraduate Students } \\
(\mathrm{N}=\mathbf{4 4})\end{array}$} & \multicolumn{4}{|c|}{$\begin{array}{l}\text { MBA Students } \\
(\mathrm{N}=\mathbf{2 5})\end{array}$} \\
\hline & Mean & Std. & Min & Max & Mean & Std. & Min & Max \\
\hline $\begin{array}{l}\text { Task } \\
\text { Performance }\end{array}$ & 3.61 & 1.631 & 0 & 7 & 3.72 & 2.319 & 0 & 8 \\
\hline $\begin{array}{l}\text { Total } \\
\text { Emotional } \\
\text { Intelligence }\end{array}$ & 118.23 & 13.100 & 88 & 152 & 120.12 & 16.438 & 85 & 155 \\
\hline Age & 23.70 & 4.811 & 20 & 42 & 32.32 & 7.198 & 24 & 48 \\
\hline $\begin{array}{l}\text { Number of } \\
\text { Accounting } \\
\text { Courses } \\
\text { Taken }\end{array}$ & 1.82 & 0.756 & 1 & 5 & $2.88^{*}$ & 1.801 & 1 & 7 \\
\hline $\begin{array}{l}\text { Work } \\
\text { Experience }\end{array}$ & 1.07 & 2.960 & 0 & 16 & 3.62 & 6.399 & 0 & 25 \\
\hline
\end{tabular}

*average of 24 students; one remaining student indicated many courses.

Table 1 above shows the descriptive statistics for undergraduate and MBA students. The mean age for students in undergraduate group was 23.70 years whereas the mean age for MBA students was 32.32 years. In the undergraduate group, the mean number of correct responses on the auditor task was 3.61 as compared to 3.72 for MBA students. Also, most of students in both students group had no work experience.

In table 2 below, we discuss the regression results. The first model evaluates the impact of undergraduate students overall EI levels on their performance in an audit task. While the overall model was insignificant, total EI was significant $(\mathrm{p}<0.05)$ 
in predicting the performance on the audit task. Both age and number of accounting courses taken did not significantly predict the performance on audit task for the undergraduate students'.

\section{Regression Model for Undergraduate Students}

Auditor Performance $(Y)=\alpha+\beta 1$ Total EI $+\beta 2$ Age $+\beta 3 \mathrm{ACCT}+\mu$

Table 2. Regression analysis for undergraduate students

$\begin{array}{ll}\text { R-square } & =0.346 \\ \text { Adjusted R-square } & =0.054 \\ \mathrm{~N} & =44 \\ \mathrm{p} \text {-value } & =.160\end{array}$

Estimated regression coefficients

\begin{tabular}{lrrrr}
\hline Parameter & Estimate & Standard Error & t-value & \multicolumn{2}{c}{ p-value } \\
\hline Intercept & -1.685 & 2.786 & -0.605 & 0.275 \\
Total EI & 0.038 & 0.019 & 2.007 & $0.026^{* *}$ \\
Age & 0.063 & 0.052 & 1.206 & 0.118 \\
ACCT & -0.386 & 0.324 & -1.190 & 0.121 \\
\hline \multicolumn{2}{c}{$* *$ Significant at $\mathrm{p}<.01 ; *$ Significant at $\mathrm{p}<.05 ;$ one-tailed }
\end{tabular}

Next, we analyze the impact of MBA students' total EI on their performance on the audit task. For this group, the entire model was insignificant, and no variables significantly explained the task performance.

Regression model for MBA students

Auditor Performance $(Y)=\alpha+\beta 1$ Total EI $+\beta 2$ Age $+\beta 3 \mathrm{ACCT}+\mu$

Table 3. Regression analysis for MBA students

$\begin{array}{ll}\text { R-square } & =0.260 \\ \text { Adjusted R-square } & =-0.073 \\ \mathrm{~N} & =25 \\ \text { p-value } & =0.699\end{array}$

Estimated Regression Coefficients

\begin{tabular}{lrrrr}
\hline Parameter & Estimate & Standard Error & t-value & \multicolumn{2}{c}{$\mathrm{p}$-value } \\
\hline Intercept & -0.548 & 4.741 & -0.116 & 0.455 \\
Total EI & 0.019 & 0.030 & 0.635 & 0.267 \\
Age & 0.074 & 0.074 & 0.999 & 0.165 \\
ACCT & -0.087 & 0.280 & -0.309 & 0.380 \\
\hline \multicolumn{2}{c}{$* *$ Significant at $\mathrm{p}<0.01 ; * *$ Significant at $\mathrm{p}<0.05 ;$ one-tailed } &
\end{tabular}


In table 4, we conduct t-tests to examine if undergraduate and MBA students exhibit significantly different levels of total EI. We also conduct t-tests to see if the two groups of students are significantly different on the different branches of EI. As shown in table 4, both undergraduate and MBA students exhibited no significant differences on any branch or total EI scores.

Table 4. T-tests of Branch and Total EI Scores

\begin{tabular}{|c|c|c|c|c|}
\hline $\begin{array}{l}\text { Branch of Emotional } \\
\text { Intelligence }\end{array}$ & $\begin{array}{l}\text { Undergraduate } \\
\text { Students } \\
\text { (mean scores) } \\
\text { (1) }\end{array}$ & $\begin{array}{l}\text { MBA } \\
\text { Students } \\
\text { (mean scores) } \\
(2)\end{array}$ & (1) - (2) & $\begin{array}{l}\text { Significance } \\
\text { (two-tailed) }\end{array}$ \\
\hline & $N=44$ & $\mathbf{N}=\mathbf{2 5}$ & & \\
\hline $\begin{array}{c}\text { Emotional Self- } \\
\text { Awareness (ESA) }\end{array}$ & 15.80 & 15.88 & -0.085 & 0.887 \\
\hline $\begin{array}{c}\text { Emotional Expression } \\
\text { (EE) }\end{array}$ & 18.09 & 17.88 & 0.211 & 0.813 \\
\hline $\begin{array}{c}\text { Emotional Awareness } \\
\text { of Others (EAO) }\end{array}$ & 16.14 & 16.08 & 0.056 & 0.928 \\
\hline $\begin{array}{c}\text { Emotional Reasoning } \\
\text { (ER) }\end{array}$ & 18.77 & 20.24 & -1.467 & 0.057 \\
\hline $\begin{array}{c}\text { Emotional Self- } \\
\text { Management (ESM) }\end{array}$ & 18.41 & 18.80 & -0.391 & 0.589 \\
\hline $\begin{array}{c}\text { Emotional } \\
\text { Management of Others } \\
\text { (EMO) }\end{array}$ & 15.77 & 15.40 & 0.373 & 0.543 \\
\hline $\begin{array}{l}\text { Emotional Self- } \\
\text { Control (ESC) }\end{array}$ & 15.25 & 18.84 & -0.590 & 0.421 \\
\hline $\begin{array}{l}\text { Total Emotional } \\
\text { Intelligence }\end{array}$ & 118.23 & 120.12 & -1.893 & 0.601 \\
\hline
\end{tabular}

\section{Discussion and conclusion}

In this paper, we provide some initial information about the relationship between EI and auditor performance and lay the foundation for a future paper that would analyze the impact of increasing the emotional intelligence awareness of auditors on their task performance. Using an audit task, we collected data on EI from 
undergraduate and MBA students, who served as surrogates for the real-life auditors. Our results do not support the hypothesis, but we encourage future researchers to consider expanding on our work as this is an important area for the field of auditing. All interested parties such as investors, regulators, audit firms and clients stand to benefit from this research. Beside our study, only a few studies have examined the relationship between emotional intelligence and auditor performance. Prior studies (Dewi \& Ramantha, 2019; Hasanuddin \& Sjahruddin, 2017; Hanafi, 2010) have found support that emotional intelligence is positively related to auditor performance and/or helps in weakening the negative influences of role conflict and unclear role on auditor performance. For example, Hasanuddin and Sjahruddin (2017) find that emotional intelligence significantly impacts the auditors' performance through work enthusiasm. However, this study collected response on a five-point Likert scale and, unlike our study, it did not develop a task for auditors to perform.

This research has implications for audit firms who can benefit by including EI skill-factor in their hiring and training decisions. The research may also help different accounting bodies such as the American Institute of Certified Public Accountants (AICPA) and the Institute of Chartered Accountants of India (ICAI) in designing course curriculum for their professional accounting certification programs (e.g., Certified Public Accountant, Certified Accountant, etc.) in a way that will produce highly emotionally intelligent auditors and accountants, thereby improving the quality of accounting and auditing. Also, mandatory periodic EI training can be provided by organizations to their employees as a stress management technique which will enhance employees' work performance (Slaski $\&$ Cartwright 2002).

If EI is found to be positively related to the auditor performance, the next question would be "Can emotional intelligence skill be enhanced in auditors through training?" In this simple experiment, we found that EI is significant $(p$-value $<.05)$ for the undergraduate student group, and therefore, it is important to review literature that suggests if EI skill can be developed. Sjolund and Gustafsson (2001) conducted a research with the employees of a construction company in Sweden to analyze if EI training can improve EI. They reported that there was a significant increase in the EI scores of the employees after they were provided a training that had EI as a part of the overall module. Similarly, several developers of EI inventory claim that EI skills can be taught to employees, and employers can witness the significant growth in their businesses and return on investments (ROI). However, given the limited literature on the effect of training EI skills on auditor performance, the impact of EI training on work performance of auditors cannot be clearly established at this time. 


\section{Limitations and future research}

In this section, we note the limitations of our study and provide recommendations for the future researchers. In this study we examined the relationship between EI and auditor performance. We did not find support for our hypothesis. One explanation for this could be that student surrogates do not mirror audit professionals. Audit professionals have special skills that go beyond what is taught in college classes and the nature of the task may have reflected more of a lack of knowledge on the part of the participants rather than the lack of impact of EI on the results. This may also explain the differences identified between undergraduate and MBA students as the undergraduate students were more likely to have had an auditing class as part of their degree program.

While we did recognize that students may not be equivalent to audit professionals, we did not want to involve professionals at this stage. First, professionals willing to participate in this or any research are in great demand and are a limited resource. Second, our goal was to run a complete study with two levels of students (undergraduate and graduate) to obtain initial evidence regarding our case materials with the idea that refinements would be necessary. Finally, despite the fact that we were not able to support our hypothesis, we believe that our work will help guide future researchers and that the area of emotional intelligence is one that has great potential for impacting individual auditors and the auditing profession. Until others see the work that is being done, with strong results or not, they may not be motivated to conduct research in this emerging area (at least in the accounting discipline). Others will now be able to make improvements before initiating related projects that will hopefully move our knowledge forward.

We further note that our study suffered from a small sample size. Our study relied on data collected from 69 students to analyze the impact of emotional intelligence on auditor performance. Finally, we did not have many variables in the study. Prior research has established that several factors such as auditors' experience and knowledge, professional skepticism, self-efficacy and professional ethical sensitivity can influence auditor performance (Sunyoto, 2020; Affifah, 2015; Peytcheva, 2014). Because of the limited sample size, we could not study and control for the impact of these factors. We encourage future researchers to utilize larger samples and include more variables in their research. Additionally, we encourage future researchers to examine the mediating role of other variables such as stress and job satisfaction on the relationship between EI and auditor task performance. 
We also encourage future researchers to develop and test different activities to test the relationship between EI and auditor performance. This will help in clearly establishing the role of EI for the audit profession. In our experiment, we did our best to provide the information that would be available in practice, however, we note that laboratory setting does not adequately replicate the professional environment, where much more information and resources are available for auditors to carry out their responsibilities. Moreover, our experiment may not adequately mimic the pressure that auditors would feel in real situations. Still, our study provides a starting point for future researchers to design their experiments and the information provided to participants was adequate for completion of the task.

Finally, we encourage researchers to utilize a wide variety of EI models to clearly establish the influence of EI on auditor task performance. We invite future researchers to explore a wide range of resources on different EI models by visiting the Consortium for Research on Emotional Intelligence in organizations (http://www.eiconsortium.org/).

\section{References}

Association of Chartered Certified Accountants (ACCA, 2018) "Emotional quotient in a digital age", available on-line at https://www.accaglobal. com/content/dam/ACCA_Global/professional-insights/Emotional_quotient/ pi-emotional-quotient-digital-age.pdf (last accessed on March 29, 2020)

Afifah, U., Sari, R. N., Anugerah, R., \& Sanusi, Z. M. (2015) "The effect of role conflict, self-efficacy, professional ethical sensitivity on auditor performance with emotional quotient as moderating variable", Procedia Economics and Finance, vol. 31: 206-212

Akers, M. D., \& Porter, G. L. (2003) "Your EQ skills: Got what it takes?", Journal of Accountancy, vol. 195, no. 3: 65-70.

Adnyana, I. W., \& Mimba, N. P. S. H. (2019) "Effect of task complexity and time pressure on auditor performance with compensation and organizational citizenship behavior (OCB) as moderation", International Research Journal of Management, IT and Social Sciences, vol. 6, no. 6: 58-67

Ashbaugh-Skaife, H., D. W. Collins, W. R. Kinney Jr., \& Lafond, R. (2009) "The Effect of SOX Internal Control Deficiencies on Firm Risk and Cost of Equity", Journal of Accounting Research, vol. 47, no. 1: 1-43

Ashton, R. H. \& Kramer, S. S. (1980) "Students as surrogates in behavioural accounting research: some evidence", Journal of Accounting Research, vol. 18 , no. 1: $1-15$.

Ayoko, O. B., Callan, V. J., \& Hãrtel, C. E. J. (2008), "The influence of team emotional intelligence climate on conflict and team members' reactions to conflict", Small Group Research, vol. 39: 121-149 
Ashforth, B. E., \& Humphrey, R. H. (1993) "Emotional labor in service roles: The influence of identity", Academy of Management Review, vol. 18: 88-115

Banker, R. D., Chang, H., \& Pizzini, M. (2011) "The judgmental effects of strategy maps in balanced scorecard performance evaluations", International Journal of Accounting Information Systems, vol. 12, no. 4: 259-279.

Brackett, M.A, Rivers, S.E., Shiffman, S., Lerner, N. \& Salovey, P. (2006) "Relating emotional abilities to social functioning: a comparison of self-report and performance measures of emotional intelligence", Journal of Personality and Social Psychology, vol. 91, no. 4: 780-795

Carcello, J. V., D. R. Hermanson, \& Huss, H.F. (2000) "Going-concern opinions: The effects of partner compensation plans and client size", Auditing: A Journal of Practice \& Theory, vol. 19, no. 1: 67-77.

Cavallo, K., \& Brienza, D. (2002) "Emotional competence and leadership excellence at Johnson \& Johnson: The emotional intelligence and leadership study", Consortium for Research on Emotional Intelligence in Organizations, $1-12$.

Clarke, N., \& Howell, R. (2010) Emotional intelligence and projects, Project Management Institute.

Daff, L., De Lange, P., \& Jackling, B. (2012) "A closer look at how emotional intelligence may be used to enhance generic skills development in accounting education" in "Proceedings of accounting and financial association of Australia and New Zealand Conference (AFAANZ 2012), Carlton, Australia, 1-3 July; 1-32

Dewi, N. P. R. A., \& Ramantha, I. W. (2019) "Effect of conflict and unclear role on auditor performance with emotional quotient as moderating variable", International journal of social sciences and humanities, vol. 3, no. 3: $50-59$

Downey, D. H. (2018) "An exploration of offshoring in audit practice and the potential consequences of associated work "redesign" on auditor performance", Auditing: A Journal of Practice \& Theory, vol. 37, no. 2: $197-223$

Druskat, V.U. \& Wolff, S.B. (2001) "Building the emotional intelligence of groups", Harvard Business Review, vol. 79, no. 3: 80-91

Ernstberger, J., Koch, C., Schreiber, E. M., \& Trompeter, G. (2020) "Are audit firms' compensation policies associated with audit quality?", Contemporary Accounting Research, vol. 37, no. 1: 218-244

Genos International (2020) Available at http://www.genosinternational.com (last Accessed on Mar 29, 2020)

Ghadhab, A. K., Matrood, A. K., \& Hameed, A. M. (2019) "Factors affecting the quality of external auditor performance: An analytical study of the opinions of auditors working in iraqi audit firms and companies", Academy of Strategic Management Journal, vol. 18, no. 1: 1-27

Gignac, G. E. (2010) “Genos Emotional Intelligence Inventory”, Technical Manual (2nd Ed.), Sydney, Waterloo, NSW, available on-line at https://www.psyjob.it/ wp-content/uploads/2012/08/GenosMan.pdf (last accessed: June 30, 2020) 
Goleman, D., Boyatzis, R. \& McKee, A. (2002) "The emotional reality of teams." Global Business and Organizational Excellence, vol. 21, no. 2: 55-65

Goleman, D. (1998) Working with emotional intelligence, New York: Bantam Books.

Gupta, G., Salter, S. B., \& Lewis, P. A. (2019) "Accounting Offshoring: The role of Emotional Intelligence", Accounting and Management Information Systems, vol. 18, no. 2: 145-172

Hasanuddin, R., \& Sjahruddin, H. (2017), "The structure of emotional intelligence, spiritual intelligence and its relationship with work enthusiasm and auditor performance", World Journal of Business and Management, vol. 3, no. 1: $67-85$

Hanafi, R. (2010) "Spiritual intelligence, emotional intelligence and auditor performance", Jurnal Akuntansi dan Auditing Indonesia, vol. 14, no. 1: 29-40

Hollingsworth, C. W., Neal, T. L., \& Reid, C. D. (2020) "The effect of office changes within audit firms on clients' audit quality and audit fees", Auditing: A Journal of Practice \& Theory, vol. 39, no. 1: 71-99

Chand, P., Cummings, L., \& Patel, C. (2012), "The effect of accounting education and national culture on accounting judgments: A comparative study of AngloCeltic and Chinese culture", European Accounting Review, vol. 21, no. 1: $153-182$

Ilarda, E., \& Findlay, B. M. (2006) "Emotional intelligence and propensity to be a team player", E-Journal of Applied Psychology, vol. 2: 19-29

Ismail, S., \& Rasheed, Z. (2019) "Influence of ethical ideology and emotional intelligence on the ethical judgement of future accountants in Malaysia", Meditari Accountancy Research, vol. 27, no. 6: 805-822

Ismail, S. (2015). "Influence of emotional intelligence, ethical climates, and corporate ethical values on ethical judgment of Malaysian auditors", Asian Journal of Business Ethics, vol. 4, no. 2: 147-162

Jacka, J. M. (2018) "How's your EQ? Emotional intelligence can help auditors build and maintain positive, productive relationships throughout the organization", Internal Auditor, vol. 75, no. 1: 36-42.

Jordan, P. J., \& Lawrence, S. A. (2009) "Emotional intelligence in teams: Development and initial validation of the workgroup emotional intelligence profile - short version (WEIP-S)", Journal of Management and Organization, vol. 15 , no. 4: 452-469.

Kearney, T., Walsh, G., Barnett, W., Gong, T., Schwabe, M. \& Ifie, K. (2017) "Emotional intelligence in front-line/back-office employee relationships", Journal of Services Marketing, vol. 31, no. 2: 185-199

Lam, L. Thi, and S. Kirby. (2002) "Is emotional intelligence an advantage? an exploration of the impact of emotional and general intelligence on individual performance", Journal of Social Psychology, vol. 142, no. 1: 133-43

Lewis, M., \& Haviland-Jones, J. M. (2000) Handbook of emotions (2nd ed.), New York: Guilford Press 
Libby, R., Bloomfield, R. and Nelson, M. W. (2002) "Experimental research in financial accounting", Accounting, Organizations and Society, vol. 27, no. 8: $775-810$

Lipe, M. G., \& Salterio, S. E. (2000) "The balanced scorecard: Judgmental effects of common and unique performance measures", The Accounting Review, vol. 75 , no. $3: 283-298$

Liyanarachchi, G. (2007) "Feasibility of using student subjects in accounting experiments: a review", Pacific Accounting Review, vol. 19, no. 1: 47-67

Mayer, J. D., Caruso, D. R., \& Salovey, P. (1999) "Emotional intelligence meets traditional standards for an intelligence", Intelligence, vol. 27, no. 4: 267-298.

Mayer, J.D. \& Salovey, P. (1997) "What is emotional intelligence?", in Salovey, P. \& Sluyter, D.J. (eds.): Emotional development and E.I.: Educational implications, New York, NY: Basic Books

Murthy, U. S., \& Wheeler, P. R. (2018) "The effects of decision-aid design on auditor performance in internal control evaluation tasks", Journal of Information Systems, vol. 32, no. 2: 95-113.

Peytcheva, M. (2014) "Professional skepticism and auditor cognitive performance in a hypothesis-testing task", Managerial Auditing Journal, vol. 29, no. 1: $27-49$

Rego, A., Sousa, F., Pina e Cunha, M., Correia, A. \& Saur-Amaral, I. (2007) "Leader self-reported emotional intelligence and perceived employee creativity: an exploratory study", Creativity and Innovation Management, vol. 16 , no. $3: 250-264$

Rice, C. L. (1999) "A quantitative study of emotional intelligence and its impact on team performance", Unpublished master's thesis, Pepperdine University, CA

Salehi, M., Mahmoudi, M. R. F., \& Gah, A. D. (2019) "A meta-analysis approach for determinants of effective factors on audit quality", Journal of Accounting in Emerging Economies, vol. 9, no. 2: 287-312

Sjölund, M., \& Gustafsson, H. (2001) "Outcome study of a leadership development assessment and training program based on emotional intelligence", An internal report prepared for the Skanska Management Institute in Stockholm, Sweden

Slaski, M., \& Cartwright, S. (2002) "Health, performance and emotional intelligence: An exploratory study of retail managers", Stress and Health: Journal of the International Society for the Investigation of Stress, vol. 18, no. 2: $63-68$

Sunyoto, Y. (2020) "Auditor's experience, professional commitment, and knowledge on financial audit performance in Indonesia", International Journal of Economics and Business Administration, vol. VIII, no. 2: 191-199

Tayler, W. B. (2010) "The balanced scorecard as a strategy-evaluation tool: The effects of implementation involvement and a causal-chain focus", The Accounting Review, vol. 85, no. 3: 1095-1117. 
Trompeter, G. (1994) "The effect of partner compensation schemes and generally accepted accounting principles on audit partner judgment", Auditing: A Journal of Practice \& Theory, vol. 13, no. 2: 56-68

Van Brenk, H., Majoor, B., \& Wright, A. (2019) "The effects of audit partner profit-sharing plans, client importance, and reinforcement sensitivity on audit quality", Working paper, Nyenrode Business University.

Victor, B., \& Cullen, J. B. (1988) "The organizational bases of ethical work climates", Administrative science quarterly, vol. 33, no. 1: 101-125

Yang, L., Brink, A. G., \& Wier, B. (2018) "The impact of emotional intelligence on auditor judgment", International Journal of Auditing, vol. 22, no. 1: 83-97

\section{Appendices}

\section{Appendix A: Genos International Emotional Intelligence Inventory (concise version)}

1. I demonstrate to others that I have considered their feelings in decisions I make at work.

2. I fail to recognize how my feelings drive my behavior at work.

3. I respond to events that frustrate me appropriately.

4. I find it difficult to identify my feelings on issues at work.

5. I express how I feel to the wrong people at work.

6. I fail to handle stressful situations at work effectively.

7. When someone upsets me at work, I express how I feel effectively.

8. I consider the way others may react to decisions when communicating them.

9. When I get frustrated with something at work, I discuss my frustration appropriately.

10. When I am under stress, I become impulsive.

11. I fail to identify the way people respond to me when building rapport.

12. I understand the things that make people feel optimistic at work.

13. I take criticism from colleagues personally.

14. I am effective in helping others feel positive at work.

15. I communicate decisions at work in a way that captures other's attention.

16. I gain stakeholders' commitment to decisions I make at work.

17. I appropriately communicate decisions to stakeholders.

18. I express how I feel at the appropriate time.

19. I understand what makes people feel valued at work.

20. I effectively deal with things that annoy me at work.

21. I appropriately respond to colleagues who frustrate me at work.

22. I find it difficult to identify the things that motivate people at work.

23. I fail to keep calm in difficult situations at work. 
24. I am aware of my mood state at work.

25. I help people deal with issues that cause them frustration at work.

26. I remain focused when anxious about something at work.

27. I fail to resolve emotional situations at work effectively.

28. I am aware of how my feelings influence the decisions I make at work.

29. I have trouble finding the right words to express how I feel at work.

30. When upset at work I still think clearly.

31. I don't know what to do or say when colleagues get upset at work.

Note: All items are measured on a five-point Likert Scale from "Almost Never (1)" to "Almost Always (5)."

\section{Appendix B: Experimental Audit Task}

You are given the financial statement of an XYZ company, whose management has been found to be corrupt in previous audits.

Please review the following financial statements and associated information (assumed to be found by you) in answering the questions given below. You may have to associate two or more pieces of information to answer these questions.

\begin{tabular}{|l|l|l|}
\hline As Reported Annual Balance Sheet & & \\
\hline Report Date & $\mathbf{3 1 - D e c - 1 0}$ & $\mathbf{3 1 - D e c - 0 9}$ \\
\hline Currency & USD & USD \\
\hline & & \\
\hline Cash \& Cash Equivalents & $5,943,000$ & $3,943,000$ \\
\hline Short-term investments & 426,000 & 192,000 \\
\hline Accounts \& notes receivable, net & $6,323,000$ & $4,624,000$ \\
\hline Raw Materials & $1,654,000$ & $1,274,000$ \\
\hline Work-in-process & 128,000 & 165,000 \\
\hline Finished Goods & $1,590,000$ & $1,179,000$ \\
\hline Inventories & $3,372,000$ & $2,618,000$ \\
\hline Prepaid expenses \& other current assets & $1,505,000$ & $1,194,000$ \\
\hline Total current assets & $\mathbf{2 0 , 9 4 1 , 0 0 0}$ & $\mathbf{1 5 , 1 8 9 , 0 0 0}$ \\
\hline & & \\
\hline Land \& improvements & $1,976,000$ & $1,208,000$ \\
\hline Buildings \& improvements & $7,054,000$ & $2,000,000$ \\
\hline $\begin{array}{l}\text { Machinery \& equipment, including fleet \& } \\
\text { software }\end{array}$ & $12,000,000$ & $17,183,000$ \\
\hline Property, plant, and equipment, gross & $33,041,000$ & $24,912,000$ \\
\hline Less accumulated depreciation & $-13,983,000$ & $-12,241,000$ \\
\hline Amortizable intangible assets, net & $2,025,000$ & 841,000 \\
\hline & & \\
\hline
\end{tabular}


Accounting and Management Information Systems

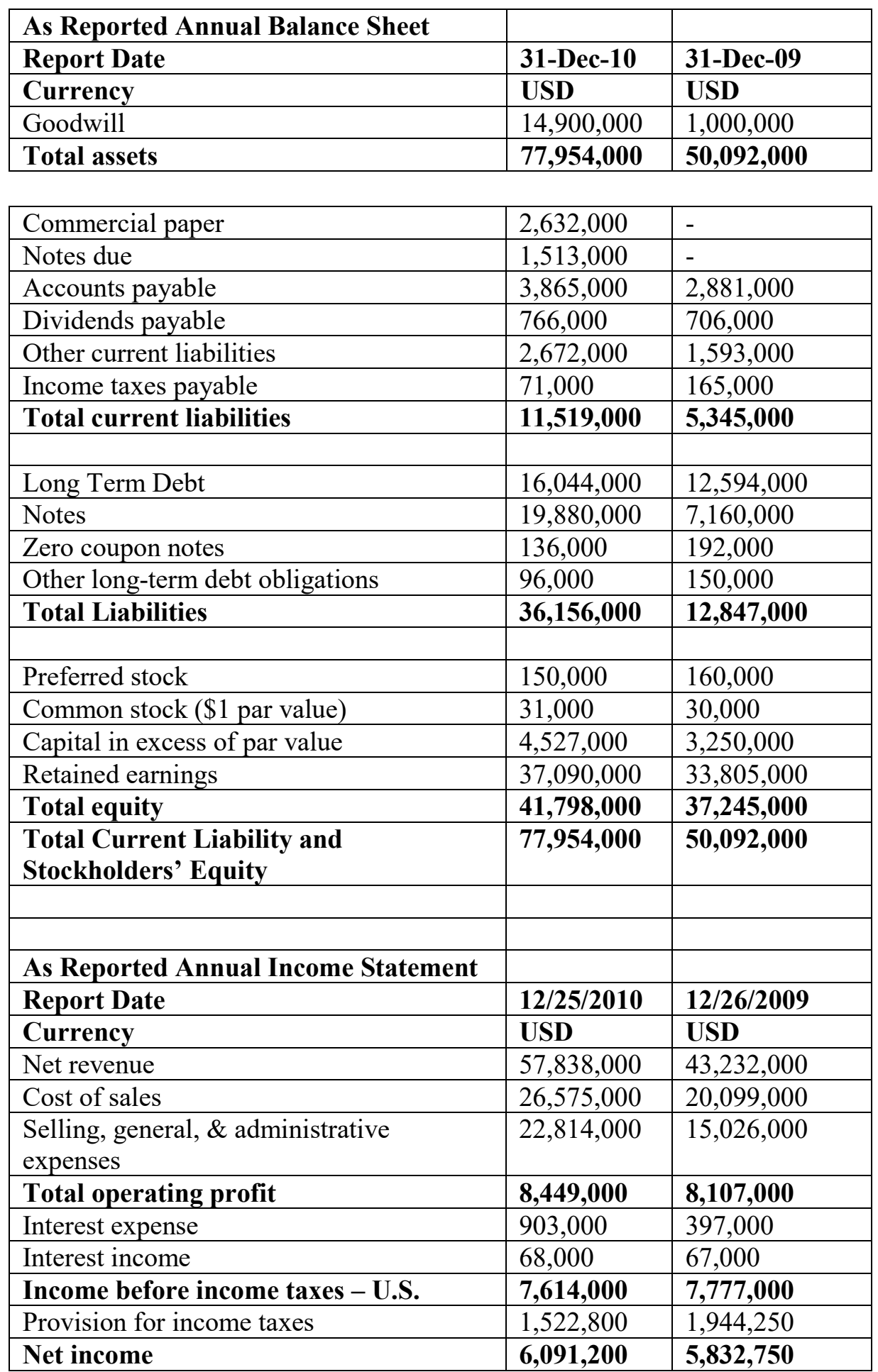

Vol. 19, No. 3 
Other Information (Assumed to be found by you)

Assume that after going through all the working papers, you have discovered the following information.

a) Sales were $80 \%$ credit and $20 \%$ cash.

b) The annual sales revenue composed of $\$ 100,000$ of sales in 2010 and 2009 for which deliveries were made on Jan $5^{\text {th }}$ of the following year.

c) You also discovered that in 2009 expenses related to rent for additional storage to the extent of $\$ 50,000$ were included as interest expenses to manipulate some profit.

d) You also find that employee stole cash to the tune of $\$ 50,000$ in year 2010, therefore, the cash amounts are under recorded.

e) Because of dishonest company management, you suspect that fraud can occur in one of the company's business areas such as inventory management, declaration of dividend, reporting of sales, etc.

f) Some inventory $(\$ 15,000)$ which was spoiled at the end of 2009 was included in 2010 .

g) Tax rate was $25 \%$ per year.

Please consider all relevant information for providing an answer. (Total 9 points)

a) The company reported that there was substantial increase in the liquidity of the company from year 2009 to 2010 . Would you regard this claim as correct? (One point)

Yes or No

b) The correct operating profits of the company should be (Two points)

Please answer this question after including all relevant information provided.

c) You have previously suspected that employee fraud has taken place wherein the employee has stolen cash. Please answer the following:

i. Actual Cash after all findings (i.e. other information). (Two points)

ii. Current Ratio. Please state the actual ratio. (Two points) 
d) You are required to find the extent of fraud that has occurred in as stated in the information above. That finding may help in answering the following questions:

i. The company reports that EPS rose by over $1 \%$ in the current year. (One point)

True or False

ii. Based on information in part i) only, would you recommend that company's financial statement is correct (One point)

True or False 